\title{
Organizational Culture and Firms' Internationalization, Innovativeness and Networking Behaviour: Hofstede Approach
}

\author{
Maja Szymura-Tyc, Michał Kucia
}

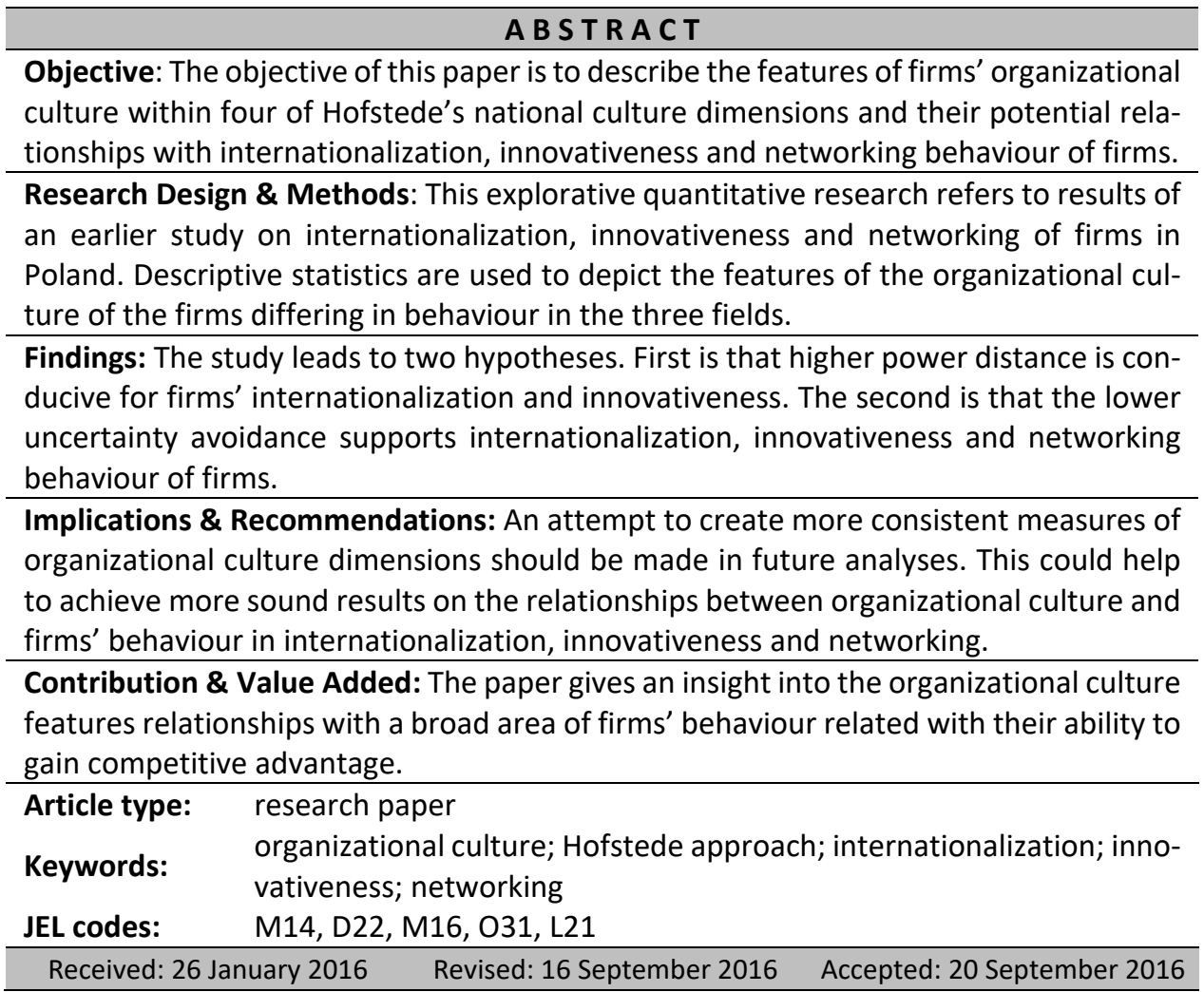

\section{Suggested citation:}

Szymura-Tyc, M., \& Kucia, M. (2016). Organizational Culture and Firms' Internationalization, Innovativeness and Networking Behaviour: Hofstede Approach. Entrepreneurial Business and Economics Review, 4(4), 67-92, DOI: http://dx.doi.org/10.15678/EBER.2016.040405 


\section{INTRODUCTION}

Organizational culture is an important factor influencing the behaviour of firms and their performance in many fields. It has a broad scope of influence and it is very difficult to change in a short-term perspective. Organizational culture is conceptualized in many ways, one of them being based on the concept of national culture introduced by Hofstede (1980). Hofstede distinguished six dimensions of national culture and four of them: power distance, collectivism vs. individualism, uncertainty avoidance and long-term orientation are translated into organizational culture features that may be related to the performance of firms. Poland as a country is characterized by high level of power distance, high individualism, very high uncertainty avoidance and short-term orientation (geert-hofstede .com/Poland).

A significant number of empirical studies demonstrate the influence of the organizational culture on the innovativeness of firms, their willingness to network or their internationalization. Hofstede's concept was used to study the impact of culture on firm level entrepreneurship (Morris, Davis \& Allen, 1994) and on entrepreneurship level of individual countries (Thomas \& Mueller, 2000; Hayton, George \& Zahra, 2002). It was also studied in the context of social networks in the international perspective (Zaheer \& Zaheer, 1997; Manev \& Stevenson, 2001). Furthermore, the concept is often employed in studies of foreign market entry modes, including joint ventures and strategic alliances, in the research conducted both on the individual countries' level and on an international scale. Finally, Hofstede's concept of culture dimensions is often related to the innovativeness and R\&D analysed for individual countries and compared internationally (Shane, 1995; Shane, Venkataraman \& MacMillan, 1995; Jones \& Teegen 2001; Kirkman, Lowe \& Gibson, 2006).

Internationalization, innovativeness and networking are the most important drivers of firms' competitive advantage today. These phenomena are to a large extent interrelated, which creates a vicious circle for firms representing a low degree of internationalization and innovativeness and unwillingness to engage in networks as is the case for many firms in transition or emerging economies. Polish firms in general represent a low level of internationalization, innovativeness and reluctance to cooperate (Szymura-Tyc, 2015a; Lewandowska, Szymura-Tyc \& Gołębiowski, 2015). The main research question that arises is whether there are any particular organizational culture features that underlie the specific firms' behaviour related to internationalization, innovativeness and networking. An answer to this question might help to understand better the organizational culture consequences for the firms' behaviour in the three fields and indicate directions of changes that might promote further development of these firms.

Hence, the general aim of this exploratory study is to describe the features of firms' organizational culture within the four above-mentioned Hofstede's dimensions of national culture, and find out their potential relationships with internationalization, innovativeness and networking behaviour of firms.

Research presented in this paper refers to results of an earlier study of internationalization, innovativeness and networking of firms in Poland conducted by one of the authors (Szymura-Tyc, 2015b). The current study is based on the empirical data collected via an internet survey. Descriptive statistics are used to depict the features of organizational culture of firms within the sample and within four clusters differing in the firms' behaviour 
in the field of internationalization, innovativeness and networking. The results and conclusions refer to both stages of the research of the organizational culture's links to internationalization, innovativeness and networking behaviour of firms.

The paper continues with the literature review related to the Hofstede's concept of national culture and its dimensions as well as his understanding of the organizational culture within these dimensions. This part of the paper also presents selected empirical research results and theoretical assumptions concerning the potential relationship between Hofstede's concept of culture and firms' behaviour in relation to innovativeness, internationalization and networking. Additionally, a short review of literature on the interrelationships between internationalization, innovativeness and networking and a brief description of prior empirical research results are included in the theoretical part of the paper. As the current study on organizational culture is exploratory in nature, the literature review only leads to the formulation of research questions. After that, the research concept is presented together with the methodology, the research instrument and the empirical research process. The results are presented in two parts: for the entire sample and within clusters of firms. Conclusions, limitations, and future research avenues are discussed at the end of the paper.

\section{LITERATURE REVIEW}

\section{Organizational Culture Concept: Hofstede Approach}

The research on cultural determinants of the internationalization, innovativeness and networking of firms is based on the concept of national culture dimensions by Geert Hofstede. Hofstede's work of 1980 titled "Culture's consequences: international differences in work related values" and his subsequent achievements form the most influential theoretical concept that is the basis for the research on the consequences of culture for the performance of nations and countries, organizations, teams and individuals. Hofstede is cited much more often than other researchers of national cultures (Trompenaars, 1993) and his work is used in thousands of empirical studies (Kirkman et al., 2006). He is also frequently criticized for various reasons (McSweeney, 2002; Smith, 2002). However, in spite of that fact, his concept underlies a lot of studies and research cases on different levels of analysis conducted by academics from many countries.

Hofstede distinguished four basic dimensions of culture: power distance (PD), collectivism vs. individualism (IDV), masculinity vs. femininity (MSC) and uncertainty avoidance (UA), the long-term orientation (LTO) added in 1991 as the fifth dimension and also the indulgency vs. restrained dimension (IND) added in 2010. Hofstede used the distinguished dimensions of culture to search for correlations between them and other measures describing the features of studied countries, which lead him to the conclusion that, in most cases, two or three dimensions have to be used to describe such dependencies (Hofstede, 2001, pp. 43-54). What is more, certain dimensions of culture are strongly correlated with one another, e.g. the power distance and the individualism have a high negative correlation (Boski, 2011, p. 100). Individualism vs. collectivism is the individual dimension of culture most frequently studied in various contexts while the power distance and uncertainty avoidance are the most frequently studied pair of dimensions. 
Even though Hofstede assumed that his concept of culture dimensions refers to nations and should not be directly applied to organizations or individuals (the need to distinguish levels of an analysis in the convention "gardens - bouquets - flowers" (Hofstede, 1995), researchers using his concept refer to individuals and groups in an organization and the organization as a whole very often. Culture is usually an independent variable in such research influencing the performance of such entities or a variable moderating relation between other variables.

The popularity of Hofstede's concept among management, entrepreneurship or international business academics probably results from that fact that the majority of Hofstede's achievements is related to the interpretation of dimensions of culture in the context of people's behaviours, which is translated, to a degree, to an organizational culture or at least to behaviour in a work place. Actually, Hofstede himself applied it to all six dimensions of culture: power distance, collectivism vs. individualism, femininity vs. masculinity, uncertainty avoidance, long-term orientation and indulgence vs. restrained (Hofstede, Hofstede \& Minkov, 2011). However, masculinity vs. femininity is a dimension describing more the attitudes of people towards the relationship between personal life and work, while indulgence vs. restrained dimension translates only into a personal behaviour at a place of work.

Having in mind the aim of the study linking the organizational culture to internationalization, innovativeness and networking behaviour of firms, four organizational culture dimensions should be taken into account: power distance, collectivism vs. individualism, uncertainty avoidance and long-term orientation. The organizational culture features based on Hofstede's national culture dimensions concept can be presented, somewhat simplified, below (Table 1).

The dimensions of an organizational culture so described by Hofstede et al. (2011) may affect the behaviour of firms in the area analysed in the study. In particular, such influence may apply to the organizational power distance (PD) and the organizational uncertainty avoidance (UA) considered in the context of innovativeness. It can also be important in internationalization of firms as some researchers define internationalization as an innovation involving an entry to a new, unknown market that requires new knowledge and is executed with an uncertainty of the attained result (Andersen, 1993, Kosała, 2015).

What might be important here is that the power distance and uncertainty avoidance are the basis for the grouping of countries in culture clusters differing in their way of thinking about an organization resulting in a strong link to its operation, including its innovativeness. The widely known classification of countries in clusters called the Machine, Pyramid, Market and Family places Poland in the Pyramid cluster as a country with a characteristic high power distance and very high uncertainty avoidance (Hofstede et al., 2011, pp. 309-315). Poland shares that cluster with Mediterranean countries that are characterized by a lower degree of innovativeness than other developed countries with a significantly lower power distance and uncertainty avoidance (e.g. Scandinavian countries, Great Britain, the United States). 
Table 1. Organizational culture features based on Hofstede national culture dimensions concept

\begin{tabular}{|c|c|}
\hline \multicolumn{2}{|c|}{ Power distance in organization } \\
\hline Low & High \\
\hline Subordinates and superiors are co-dependent & Subordinates are dependent on superiors \\
\hline $\begin{array}{l}\text { Superiors consult their decisions with subordinates } \\
\text { using their own experience and the experience } \\
\text { of subordinates }\end{array}$ & $\begin{array}{l}\text { Superiors make decisions without consultations with } \\
\text { subordinates on the basis of the superiors' experience } \\
\text { and formal regulations }\end{array}$ \\
\hline $\begin{array}{l}\text { Occupying top positions does not entail substantially } \\
\text { higher salaries and special privileges }\end{array}$ & $\begin{array}{l}\text { Occupying top positions entails substantially higher } \\
\text { salaries and special privileges }\end{array}$ \\
\hline $\begin{array}{l}\text { Employees occupying lower positions perform } \\
\text { different roles in the enterprise than employees } \\
\text { on higher levels }\end{array}$ & $\begin{array}{l}\text { Employees occupying lower positions have lesser } \\
\text { abilities and skills than employees on higher levels }\end{array}$ \\
\hline $\begin{array}{l}\text { Important decisions are made on different levels } \\
\text { and do not require strict control in the course } \\
\text { of their execution }\end{array}$ & $\begin{array}{l}\text { Important decisions are made on top levels and require } \\
\text { strict control in the course of their execution }\end{array}$ \\
\hline \multicolumn{2}{|c|}{ Collectivism and individualism in organization } \\
\hline Collectivism & Individualism \\
\hline $\begin{array}{l}\text { Employees strive to act in the interest of the group } \\
\text { they are part of }\end{array}$ & Employees strive to act in their own interest \\
\hline $\begin{array}{l}\text { Decisions concerning employees' salary and promo- } \\
\text { tion depend on their membership in a group and } \\
\text { achievements of the group }\end{array}$ & $\begin{array}{l}\text { Decisions concerning employees' salary and promotion } \\
\text { depend on the regulations in force and their individual } \\
\text { achievements }\end{array}$ \\
\hline $\begin{array}{l}\text { Even if someone has a different opinion, she/he } \\
\text { should adapt to the opinion of the collective }\end{array}$ & $\begin{array}{l}\text { Everyone can have a different opinion and is expected } \\
\text { to express it }\end{array}$ \\
\hline $\begin{array}{l}\text { Interpersonal relations are more important than } \\
\text { the execution of tasks }\end{array}$ & $\begin{array}{l}\text { The execution of tasks is more important than inter- } \\
\text { personal relations }\end{array}$ \\
\hline $\begin{array}{l}\text { Relations between the employer and the employee } \\
\text { resemble family ties }\end{array}$ & $\begin{array}{l}\text { Relations between the employer and the employee } \\
\text { are reduced to the employment contract }\end{array}$ \\
\hline \multicolumn{2}{|c|}{ Uncertainty avoidance in organization } \\
\hline Low & High \\
\hline $\begin{array}{l}\text { Change is more desirable than preservation } \\
\text { of the current situation }\end{array}$ & $\begin{array}{l}\text { Preservation of the current situation is more desirable } \\
\text { than a change }\end{array}$ \\
\hline $\begin{array}{l}\text { Innovative and creative employees have more } \\
\text { freedom }\end{array}$ & $\begin{array}{l}\text { Innovative and creative employees are limited } \\
\text { by regulations }\end{array}$ \\
\hline $\begin{array}{l}\text { Managers mainly focus on strategic issues and, } \\
\text { to a lesser degree, on operational activities }\end{array}$ & $\begin{array}{l}\text { Managers mainly focus on operational activities and, } \\
\text { to a lesser degree, on strategic issues }\end{array}$ \\
\hline $\begin{array}{l}\text { Few matters are regulated in detailed regulations } \\
\text { and they are usually complied with }\end{array}$ & $\begin{array}{l}\text { Many matters are regulated in detailed regulations } \\
\text { but they are not always complied with }\end{array}$ \\
\hline $\begin{array}{l}\text { Many ideas/inventions are generated but } \\
\text { not all are implemented }\end{array}$ & $\begin{array}{l}\text { Few ideas/inventions are generated but most of them } \\
\text { are implemented }\end{array}$ \\
\hline \multicolumn{2}{|c|}{ Short and long orientation of organization } \\
\hline Short-term orientation & Long-term orientation \\
\hline $\begin{array}{l}\text { Actions taken are evaluated from the perspective } \\
\text { of their effects in annual periods }\end{array}$ & $\begin{array}{l}\text { Actions taken are evaluated from the perspective } \\
\text { of their effects in many years' periods }\end{array}$ \\
\hline $\begin{array}{l}\text { Relations with business partners are evaluated from } \\
\text { the perspective of short-term profits }\end{array}$ & $\begin{array}{l}\text { Relations with business partners are evaluated from } \\
\text { the perspective of long-term profits }\end{array}$ \\
\hline $\begin{array}{l}\text { Meeting the deadline for a task completion is more } \\
\text { important than attaining an expected result }\end{array}$ & $\begin{array}{l}\text { Attaining an expected result is more important than } \\
\text { meeting the deadline for a task completion }\end{array}$ \\
\hline $\begin{array}{l}\text { A fast, spectacular market or financial success is } \\
\text { more important than the gradual building of a strong } \\
\text { market position }\end{array}$ & $\begin{array}{l}\text { Building of a strong market position gradually is more } \\
\text { important than a fast, spectacular market or financial } \\
\text { success }\end{array}$ \\
\hline $\begin{array}{l}\text { Objectives of the managerial staff and employees } \\
\text { diverge }\end{array}$ & $\begin{array}{l}\text { Objectives of the managerial staff and employees } \\
\text { converge }\end{array}$ \\
\hline
\end{tabular}

Source: own elaboration based on Hofstede et al. (2011, pp. 83-86; 127-133; 215-223; 250-258). 
The organizational power distance and the organizational uncertainty avoidance may be also supplemented with the third organizational dimension - the individualism/collectivism (IDV). Sułkowski (2012) applies such a three-dimensional model of an organizational culture in the description of firms' behaviour in the management process, linking it with their competitive potential.

It is worth mentioning that Hofstede (2011) pointed out that the culture profile of Poland houses a contradiction resulting from high individualism (IDV) and high power distance (PD), which are usually negatively correlated. This contradiction creates a specific tension in Polish culture and a challenge for mangers. To achieve fruitful results managers are advised to establish a second level of communication, having a personal contact with everybody in the structure, allowing to give the impression that "everybody is important" in the organization, although unequal (geert-hofstede.com/Poland).

The individualism/collectivism in organization dimension (IDV) alone may also have a potential significance for the networking i.e. the willingness of a firm to create network ties. It may influence the perception of individual and mutual interest, be connected with opportunistic attitudes toward business partners, result in the lack of trust and loyalty in business relationships. Combined with very high uncertainty avoidance (UA), high level of individualism may limit the firms' openness for cooperation within networks.

Considering the fact that both firms' innovativeness and internationalization require investments that bring about effects in a longer term, one should also take a fourth dimension into account, i.e. the organizational long-term/short-term orientation. This dimension may also appear significant in the process of creation of firms' long lasting relationships with business partners that provide basis for a network development.

\section{Internationalization, Innovativeness and Networking: Interrelationships}

The dominating model of firms' internationalization today is the network model of internationalization (Johanson \& Mattsson, 1988; Johanson \& Vahlne, 2009). The model describes the process of internationalization as a process of learning through networks (Sharma \& Blomstermo, 2003; Blomstermo, Eriksson, Lindstrand \& Sharma, 2004; Coviello, 2006). It assumes that knowledge exploitation enables the firm to expand on well-known paths of development only and reduces the risk of increased resource commitment in foreign market. The knowledge exploration from external sources, i.e. from partners in the network, allows for experimentation to explore new possibilities with higher risk but also higher potential profits in the longer term (Forsgren, 2002; Sharma \& Blomstermo, 2003).

Eriksson, Majkgård and Sharma (2000) state that the experiential knowledge of a firm may be a barrier for its further internationalization as it limits the ability to recognize new possibilities for international development. The network ties, indirect and weak with multiple partners rather than direct and strong with few partners, offer an access to knowledge and resources of the network partners valuable for international expansion. Combined with the knowledge and resources of the firm, the network ties speed up and support the process of internationalization (Coviello \& Munro, 1995; Sharma \& Blomstermo, 2003; Coviello, 2006; Majkgård \& Sharma, 1998; Bell, 1995). Forsgren (2002) and Johanson and Vahlne (2009) state that the network model of internationalization is universal as it describes how both small and medium firms (e.g. born global, new international ventures) and large corporations internationalize their activity by learning in networks. 
Similarly, the network model of innovation (Rothwell, 1992) has been the model of innovation dominating since the early 90 s. It explains the innovation process as a process of inter-organizational learning (Calantone, Cavusgil \& Zhao, 2002) or network learning in innovation networks (Dhanaraj \& Parkhe, 2006). The innovation processes span the firms' borders to integrate and share knowledge and resources of multiple partners needed for successful innovation. Innovation is created within networks that emerge as a result of the longitudinal cooperation between business partners or in networks engineered intentionally to create and support innovations. Powell, Koput and Smith-Doerr (1996) prove that if the knowledge base in an industry is complex and the sources of expertise are dispersed, innovation may be not created in a single firm and inter-organizational innovation cooperation is necessary. Access to the developing and evolving learning community becomes a critical factor for competitive advantage in the industry.

Furthermore, international business literature has been discussing relationships between internationalization and innovativeness of firms for a long time. The majority of studies on such relationships concentrate on the dependence between internationalization and innovativeness assuming that firms' internationalization is a result of their innovation activity or, more generally, is determined by their innovativeness. Empirical firmlevel studies conducted in numerous countries and sectors generally confirm a positive link between innovation and exporting (Basile, 2001; Roper \& Love, 2002; Becker \& Egger, 2009). The other stream of research focuses on the opposite, presuming that internationalization can stimulate innovativeness because it offers access to new knowledge, more demanding customers and challenges of the international competitiveness (Gupta \& Govindarajan, 2000; Zahra, Ireland \& Hitt, 2000). Therefore, the innovativeness of a firm may be the outcome of a firm's preceding involvement in international market by exports and learning by exporting is considered to be leading to an increased innovativeness of a firm (Salomon \& Shaver, 2005; Salomon \& Jin, 2008).

The findings of three research streams combined have led to a hypothesis that the internationalization, innovativeness and networking are interrelated. The empirical research performed by the one of the authors has confirmed that positive relationships exist between all three concepts: internationalization, innovativeness and networking (Szymura-Tyc \& Łapczyński, 2012). The empirical research conducted by direct questionnaire interview covered 274 firms located in Poland. Firstly, the collected data has allowed for the measuring of the firms' degree of internationalization, innovativeness and networking with the use INT, INN and NET indices based on formative indicators. The measures indicated a low degree of internationalization, medium innovativeness and a relatively high degree of networking of the studied firms. Secondly, the analysis of relationships between internationalization, innovativeness and networking demonstrated positive although weak to moderate correlations between all the three indices. Thirdly, the research showed that there were significant differences in the firms' behaviour in the field of internationalization, innovativeness and networking. The firms with similar values of the INT, INN and NET indices have been grouped with the use of a cluster analysis called self-organizing maps (SOM) or the Kohonen network (Kohonen, 1990). As a result, four clusters of firms with different characteristics of behaviour in the internationalization, innovativeness and networking area were distinguished. Graphical illustration of the clusters identified by the SOM method is presented in Figure 1. 


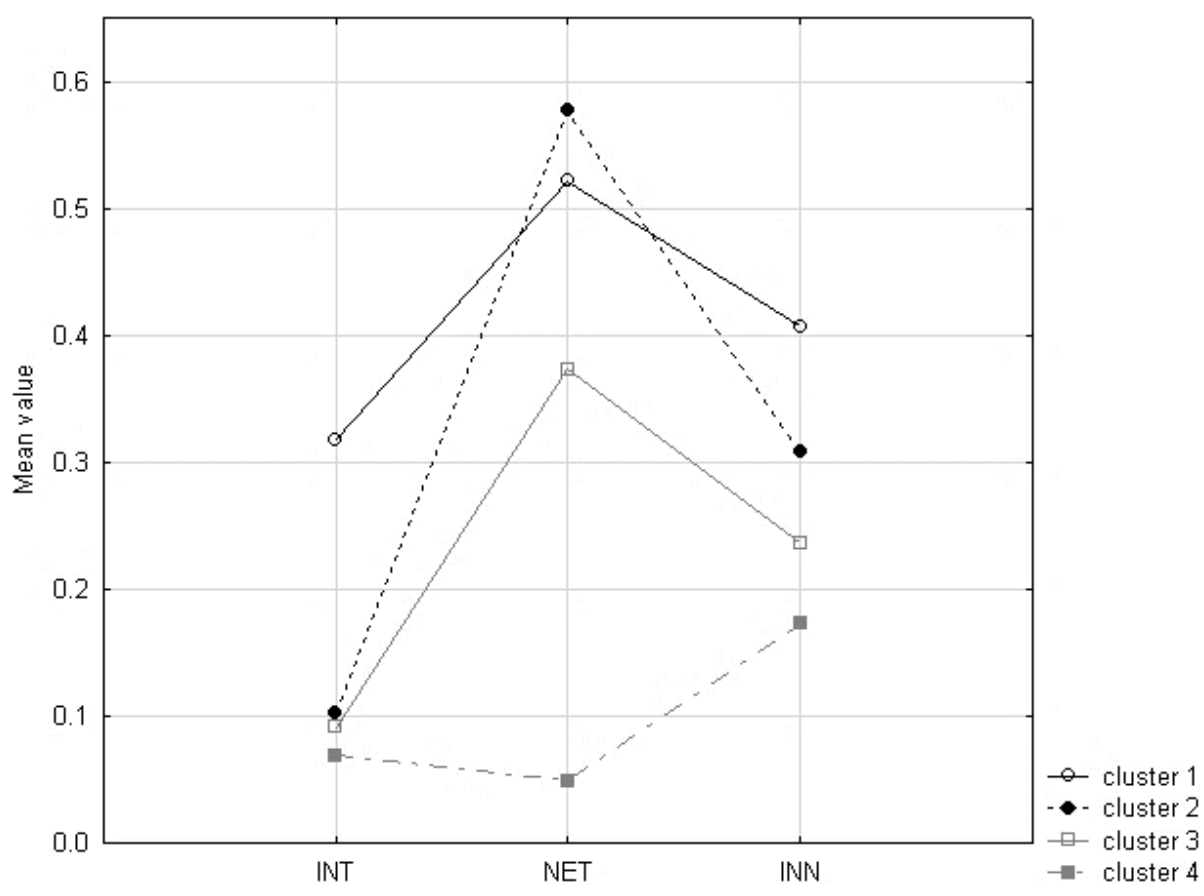

Figure 1. Clusters of enterprises distinguished with the use of the SOM method $(n=274)$ Source: Szymura-Tyc (2015b, p. 187); Szymura-Tyc and Łapczyński (2012, p. 298).

Firms in the first cluster (SOM 1) have a moderate degree of internationalization, high degree of innovativeness and high degree of networking. These firms may be called "international network and innovation high-fliers". The second cluster (SOM 2) contains firms with low internationalization, moderate innovativeness and high networking degree called "local innovation and network front-runners". The third cluster (SOM 3) consists of firms with low degree of internationalization, moderate innovativeness and moderate networking named "local innovation and network commoners". The fourth cluster (SOM 4) embraces firms with the lowest internationalization, innovativeness and networking labelled "local innovation and network laggards".

The analysis of relationships between the degree of internationalization, innovativeness and networking of the studied firms belonging to individual clusters made it possible to make certain assumptions regarding the dependence path in the analysed area. As for the first cluster, it was assumed that a relatively high internationalization degree was conducive to high innovativeness, both being supported by a high networking degree of the firms. Regarding cluster two, it was presumed that a moderate innovativeness of firms could not be linked to their internationalization as it was not very high. However, the innovativeness of these firms can be "drawn" by their network ties as these firms are characterized by the highest degree of the networking in the studied population. In the third cluster, consisting of firms whose internationalization resembles the internationalization of firms belonging to the second cluster, the innovativeness degree that is lower in the second cluster can be due to a much lower degree of networking. The last cluster consisted 
of firms operating mainly on a local market with the lowest innovativeness accompanied by the markedly lowest networking that could "pull down" their innovativeness.

The findings described above concerning the firms' behaviour in internationalization, innovativeness and networking fields as well as rather general knowledge of the potential influence of organizational culture on this behaviour resulted in further research assumptions leading for the explorative study presented in this paper. The first assumption is that the actual degree of internationalization, innovativeness and networking of the studied firms may be related to some extent to their organizational culture features. The second assumption is that differences in firms' behaviour identified by the cluster analysis may be dependent on the differences in the organizational cultures of firms in the particular clusters.

As a result, the objective of the current stage of the research has been to answer the following research questions:

- What are the features of the organizational culture of the studied firms in the context of the Hofstede's concept of national culture dimensions?

- May the distinguished features of organizational culture be related with the firms' behaviour in the internationalization, innovativeness and networking fields?

- Are the firms belonging to the individual clusters characterised by different features of their organizational cultures?

- May the differences in the organizational culture features within individual clusters be related to the different firms' behaviour in internationalization, innovativeness and networking fields?

\section{MATERIAL AND METHODS}

\section{Research Instrument and Research Process}

The organizational culture is treated in the study as a variable independent from the internationalization, innovativeness and networking of firms. It is divided into four dimensions: power distance, collectivism/individualism., uncertainty avoidance, and short/longterm orientation. The dimensions of the organizational culture are constituted by features assigned by Hofstede to the individual dimensions of national culture as presented in table 1.

The explorative empirical study is based on an internet survey with the use of a questionnaire developed for the quantitative research. The research instrument contained five questions related to situations occurring in the surveyed firms within each of the four dimensions of their organizational culture. Respondents were asked to indicate whether any of the described situations: (1) corresponds to the situation in the firm to a degree; (2) greatly corresponds to the situation in the firm; (3) fully corresponds to the situation in the firm. They could also indicate (0) if, in their opinion, none of the described situations prevailed in the firm. All of the provided answers created a 7-items Likert-type bipolar scale referring to the opposing designations of features of the organizational culture within its individual dimensions. This type of scale is commonly used in psychometric studies to measure attitudes and behaviours by ascribing values to qualitative answer choices that range from one extreme to another. For example, the short/long-term orientation scale ranged from 1 to 7 , where 4 represented a situation in which none of the described situations prevailed in a firm. Respondents were not aware to which of the opposite culture 
features descriptions lower scores were assigned corresponding to a lower level of the studied dimension and to which of them higher scores were assigned indicating its higher level. It was possible thanks to a random reversal of the opposite culture features descriptions within the individual culture dimensions, which is in line with the recommendation for this research technique (Osgood, Suci \& Tannenbaum, 1957). After collecting the data, the answers were assigned proper values and results were subjected to the statistical descriptive analysis. The long-lasting disagreement among statisticians whether the Likert items are interval-level data or ordered-categorical data inclined the authors to adopt a compromise in the form of the presentation of all three measures of the central tendency: mode, median and mean. The means for individual organizational culture features are presented in the paper because the authors share the prevailing opinion that if the Likert-type scale is symmetric and equidistant it may be treated as a quasi-interval scale allowing for the calculation of scores for a group of items.

\section{Research Sample and Respondents}

The target of the internet survey consisted of all the 274 firms participating in the first stage of the research. Therefore, each survey was preceded by on-the-phone conversations with respondents in order to invite and encourage them to participate in the second stage of the research. An attempt was also made to obtain a proportional number of firms in each of the four clusters distinguished in the earlier study. As a result, 130 firms completed the entire electronic survey questionnaire. It means that the return rate is $47 \%$ of the firms whose internationalization, innovativeness and networking was studied previously. A relatively proportional number of firms was also obtained in each of the four clusters: respectively $66 \%, 42 \%, 41 \%$ and $61 \%$ of the firms in a cluster.

It was assumed at the beginning of the empirical research that respondents participating in the survey should be members of the top or medium-level management of firms. It is because Hofstede's cultural research shows that the perception of the culture dimensions can vary depending on the social position of a respondent. It was not easy to attain that goal. As a result, top and medium-level management constitute about 30\%, while specialists and accountants make for another $30 \%$, and management assistants and secretaries form almost one fourth of respondents (Table 2). The majority of respondents has at least 6 years of employment history and the average employment history is 8 years. This fact may be a symptom of the respondents' good knowledge of the organizational culture of studied firms.

Table 2. Characteristics of respondents $(n=127)^{*}$

\begin{tabular}{|l|c|}
\multicolumn{1}{|c|}{ Position in the firm } & Share in the sample [\%] \\
\hline Top and medium-level management & 27.7 \\
\hline Specialists and accountants & 30.0 \\
\hline Management assistants /secretaries & 23.8 \\
\hline Other positions & 18.5 \\
\hline
\end{tabular}

* in three cases, respondents did not provide the information about the occupied position. Source: own study. 


\section{RESULTS AND DISCUSSION}

The analysis of features comprising individual dimensions of the organizational culture was conducted for the entire sample and in individual SOM clusters. The goal of the conducted analyses was to identify the features of organizational cultures in all firms subject to the research and their differentiation depending on the type of behaviour related to the internationalization, innovativeness and networking. The descriptive statistics used in the study are mode (Mo), median (Me) and mean (M). The mode shows the value with highest frequency of answers, the median divides the sample into equal parts showing the central value for a feature, while the mean is the arithmetic mean of the values ascribed to an organizational culture feature in a sample. It is assumed that the 1-3 modes and medians represent, respectively, a very low, low and moderate low level of a culture feature within a given dimension, 4-moderate, and 5-7 - moderately high, high and very high level respectively. As far as the means are concerned, the 1-3.5 value consistently indicates a very low to moderately low level of a feature; 3.6-4.4 - moderate and 4.5-7 - a moderately high to very high level.

\section{Characteristics of Organizational Cultures Features in Entire Sample}

The first step of the analysis was the description of cultural features for the whole research sample within the four studied dimensions: power distance, individualism, uncertainty avoidance and long term orientation. For detailed descriptive statistics see Appendix 1.

\section{Power Distance in an Organization}

The analysis of the frequency of indications related to the power distance in an organization shows that the largest number of the surveyed firms assess the dimension as low or moderately low. The prevailing opinion is that subordinates and superiors are co-dependent, occupying top positions does not entail substantially higher salaries or special privileges while important decisions are made on different levels and do not require strict control in the course of their execution. The only exception is the prevailing belief that employees occupying lower positions have lesser abilities and skills than employees on higher levels, which suggests a greater power distance in the organization. Median values are between 3-4, which means that half of the firms report a moderately low to moderate level of the power distance organizational culture features. The highest mean denotes the way of making decisions by superiors without consultations with subordinates indicating a more authoritarian style of the firms' managers. The situation is similar for means within 3.53-4.08, which suggests a moderately low to moderate power distance in the entire sample. The highest mean denotes the way of making decisions by superiors without consultations with subordinates indicating a more authoritarian style of the firms' managers. 


\section{Individualism in an Organization}

The analysis of survey data on individualism vs. collectivism in the studied firms shows the prevalence of opinions denoting a moderately high level of individualism. It is reflected by the indication that employees strive to act in their own interest, that everyone can have a different opinion and is expected to express it, that the execution of tasks is more important than interpersonal relations and that relations between the employer and the employee are reduced to the employment contract. It was only with regard to salaries that the largest number of respondents pointed at a moderately low level of individualism reflected by the fact that decisions concerning employee salaries and promotions depend on their membership in a group and achievements of the group rather than on their individual achievements. In spite of the prevalence of symptoms of a moderately high level of individualism in the firms, the median value ranges from 4 to 4.5 indicating a moderately high level of individualism in one half of the sample. The mean values describing the organizational culture range from 3.77 to 4.24 depicting a moderate level of individualism in the entire research sample.

\section{Uncertainty Avoidance in Organization}

The situation is similar for the level of uncertainty avoidance in the surveyed firms where prevalent responses are indicative of a moderately high uncertainty avoidance. It is pointed out that innovative and creative employees are limited by regulations, many matters are regulated in detailed regulations that are not always complied with. While few ideas/inventions are generated, most of them are implemented. In the case of the managerial focus, the largest number of respondents indicated a high level of uncertainty avoidance reflected by the fact the managers mainly focus on operational activities and, to a lesser degree, on strategic issues. Only the dominance of an indication that change is more desirable than the current situation might signal a lower level of uncertainty avoidance. As far as the median values are concerned, they suggest a moderately high and moderate level of uncertainty avoidance, which is also reflected in the mean values describing the organizational culture features within the range of 3.67-4.53, representing moderate and moderately high uncertainty avoidance in the studied firms.

\section{Long-Term Orientation in an Organization}

As far as the short-term vs. long-term orientation in organization is concerned, the dominance of indications of the long-term orientation suggests a high level of this dimension in the entire sample. The respondents point out that actions taken in a firm are evaluated from the perspective of their effects in many years' periods, relations with business partners are evaluated from the perspective of long-term profits, attaining an expected result is more important than meeting the deadline for a task completion and objectives of the managerial staff and employees converge. It was only in the case of the general aim of a firm described as the company building a strong market position gradually rather than striving to achieve a fast, spectacular market or financial success, that the largest number of firms supported it at a moderately high level. In most cases, median values report the moderately high level of long-term orientation as central in the sample, while the mean values of the organizational culture range from 4.17 to 4.68 , representing the moderate to moderately high level of the long-term orientation dimension in surveyed firms - the 
lowest one for the time perspective in business partners relationships assessment and the longest one in the evaluation of activities conducted within the firm.

To sum it up, research results for the entire sample of surveyed firms show that the power distance (PD) is at a moderate level with a tendency towards moderately low, the individualism (IDV) is moderate with a tendency towards moderately high, the uncertainty avoidance (UA) is also moderate towards moderately high and the long-term orientation (LTO) is moderately high with a tendency towards a high level of this dimension (Table 3).

Table 3. Evaluation of the organizational culture features within the Hofstede's dimensions $(n=130)$

\begin{tabular}{|c|c|c|c|}
\hline \multirow{2}{*}{$\begin{array}{l}\text { Organizational culture } \\
\text { dimension }\end{array}$} & \multicolumn{3}{|c|}{ Evaluation of culture features } \\
\hline & by dominant value (Mo) & by central value (Me) & by mean values (M) \\
\hline power distance & $\begin{array}{l}\text { low (3) } \\
\text { moderate low (1) } \\
\text { moderate high (1) }\end{array}$ & $\begin{array}{l}\text { moderate low (4) } \\
\text { moderate (1) }\end{array}$ & $\begin{array}{l}\text { moderate low (2) } \\
\text { moderate (3) }\end{array}$ \\
\hline individualism & $\begin{array}{l}\text { moderate low (1) } \\
\text { moderate high (4) }\end{array}$ & $\begin{array}{l}\text { moderate (4) } \\
\text { moderate high (1) }\end{array}$ & moderate (5) \\
\hline uncertainty avoidance & $\begin{array}{l}\text { moderate low (1) } \\
\text { moderate high (3) } \\
\text { high (1) }\end{array}$ & $\begin{array}{l}\text { moderate ( } 2 \text { ) } \\
\text { moderate high (3) }\end{array}$ & $\begin{array}{l}\text { moderate (4) } \\
\text { moderate high (1) }\end{array}$ \\
\hline long-term orientation & $\begin{array}{l}\text { high (4) } \\
\text { moderate high (1) }\end{array}$ & $\begin{array}{l}\text { moderate (1) } \\
\text { moderate high (4) }\end{array}$ & $\begin{array}{l}\text { moderate (2) } \\
\text { moderate high (3) }\end{array}$ \\
\hline
\end{tabular}

$(1,2, \ldots)$ - numbers in brackets represent the number of organizational culture features which are ascribed the particular assessment

Source: own study.

Having in mind that the degree of internationalization for the entire sample is low, the innovativeness is moderate and the networking - relatively high, the power distance (PD) and individualism (IDV) could be expected at least at a moderate level, uncertainty avoidance (UA) - at a high level and the long-term orientation (LTO) at a level that is not higher than moderate. The results go in line with the expectations regarding the individualism and uncertainty avoidance. However, the power distance is lower than expected and the most surprising results show that the long-term orientation is moderately high.

The results are not easy to discuss in the light of other researchers' findings as the scope of the study is very broad. This fact stands for the originality of the study but, on the other hand, it limits the comparative analysis. Furthermore, latent variables being the basis for calculation of the internationalization, innovativeness and networking indices are built on formative variables, which is not a common practise in studies concerning cultural determinants of firms' behaviour in the field of innovativeness or networking.

\section{Characteristics of Organizational Culture Features in SOM Clusters}

The second step of the exploratory study involved a description of the organizational culture features in all four dimensions separately for each of the identified clusters. The detailed descriptive statistics are provided in the Appendix 2. 


\section{International Network and Innovation High-Fliers (SOM1)}

Firms belonging to SOM1 named "the international network and innovation high-fliers" are characterised by a moderate internationalization, high innovativeness, and high networking. In the case of the power distance (PD), firms from this cluster most often declare a moderately high or high level of power distance in their organizational culture. However, the median value predominantly indicates a moderate level of features describing this dimension and the same applies to the mean values pointing at a moderate power distance for all features constituting the power distance dimension. As far as individualism is concerned (IDV), there is a lack of consistency of the dominant values; each feature of culture has a different mode. Both the median and the mean range from moderately low to moderately high and most probably the moderate level would be the one that describes the level of individualism in SOM1 best. Uncertainty avoidance (UA) is described as moderate to very high, however, a moderate level may be considered most frequently related to the organizational culture features comprising this dimension. As for the long-term orientation (LTO), conclusions may be made on the basis of the medians and means most frequently reflecting a moderately high level of the features depicting this dimension of the firms' culture (Table 4).

Table 4. Evaluation of the organizational culture features within the Hofstede's dimensions in SOM1 $(n=27)$

\begin{tabular}{|l|l|l|l|}
\hline \multirow{2}{*}{$\begin{array}{c}\text { Organizational culture } \\
\text { dimension }\end{array}$} & \multicolumn{3}{|c|}{ Evaluation of organizational culture features } \\
\cline { 2 - 4 } power distance & $\begin{array}{l}\text { moderate high (1) } \\
\text { high (1) }\end{array}$ & $\begin{array}{l}\text { moderate (4) } \\
\text { moderate high (1) }\end{array}$ & moderate (5) \\
\hline \multirow{2}{*}{ individualism } & $\begin{array}{l}\text { low (1) } \\
\text { moderate low (1) } \\
\text { moderate (1) } \\
\text { moderate high (1) } \\
\text { high (1) }\end{array}$ & $\begin{array}{l}\text { moderate low (2) } \\
\text { moderate (1) } \\
\text { moderate high (2) }\end{array}$ & $\begin{array}{l}\text { moderate low (1) } \\
\text { moderate (3) } \\
\text { moderate high (1) }\end{array}$ \\
\hline uncertainty avoidance & $\begin{array}{l}\text { moderate high (2) } \\
\text { high (1) }\end{array}$ & $\begin{array}{l}\text { moderate (2) } \\
\text { moderate high (3) }\end{array}$ & $\begin{array}{l}\text { moderate (4) } \\
\text { moderate high (1) }\end{array}$ \\
\hline long-term orientation & $\begin{array}{l}\text { moderate (1) } \\
\text { very high (1) }\end{array}$ & $\begin{array}{l}\text { moderate (1) } \\
\text { moderate high (4) } \\
\text { moderate (2) }\end{array}$ \\
\hline
\end{tabular}

$(1,2, \ldots)$ - numbers in brackets represent the number of organizational culture features which are ascribed the particular assessment; if in case of modes the numbers do not sum to 5 multimodal distribution appeared for some features of organizational culture

Source: own study.

\section{Local Innovation and Network Front Runners (SOM2)}

Firms constituting the SOM2 are described as "local innovation and network front runners" because they are characterised by low internationalization, moderate innovativeness and high networking. The power distance (PD) level in this cluster may be described by medians and means that show a moderately low to moderate level of the organizational culture features under study, with the prevalence of indications towards a moderately low power distance. Individualism (PD) is also moderate as suggested by the central values and means describing the level of cultural features within this dimension. Uncertainty avoidance (UA) is moderate or moderately high as regards most of the culture feature; however, 
it is on a moderate level that prevails in these results. The last dimension, i.e. the longterm orientation (LTO) is characterized by a moderate and moderately high level of features constituting it and it is difficult to compare them; however, the frequency of answers may suggest that moderately high can be a better evaluation of this dimension level in the cluster (Table 5).

Table 5. Evaluation of the organizational culture features within the Hofstede's dimensions in SOM2 $(n=48)$

\begin{tabular}{|l|l|l|l|}
\hline \multirow{2}{*}{$\begin{array}{c}\text { Organizational culture } \\
\text { dimension }\end{array}$} & \multicolumn{3}{|c|}{ Evaluation of organizational culture features } \\
\cline { 2 - 4 } power distance & by dominant value (Mo) & \multicolumn{1}{|c|}{ by central value (Me) } & by mean values (M) \\
\hline \multirow{2}{*}{ individualism } & $\begin{array}{l}\text { low (4) } \\
\text { moderate high (1) }\end{array}$ & $\begin{array}{l}\text { moderate low (4) } \\
\text { moderate high (1) }\end{array}$ & $\begin{array}{l}\text { moderate low (2) } \\
\text { moderate (3) }\end{array}$ \\
\hline $\begin{array}{l}\text { moderate (1) } \\
\text { moderate high (2) } \\
\text { high (1) }\end{array}$ & $\begin{array}{l}\text { moderate (4) } \\
\text { moderate high (1) }\end{array}$ & moderate (5) \\
\hline uncertainty avoidance & $\begin{array}{l}\text { low (1) } \\
\text { moderate high (4) } \\
\text { high (1) }\end{array}$ & $\begin{array}{l}\text { moderate low (1) } \\
\text { moderate (2) } \\
\text { moderate high (2) }\end{array}$ & $\begin{array}{l}\text { moderate (4) } \\
\text { moderate high (1) }\end{array}$ \\
\hline long-term orientation & $\begin{array}{l}\text { moderate low (1) } \\
\text { moderate high (1) } \\
\text { high (2) }\end{array}$ & $\begin{array}{l}\text { moderate (1) } \\
\text { moderate high (4) }\end{array}$ & $\begin{array}{l}\text { moderate (4) } \\
\text { moderate high (1) }\end{array}$ \\
\hline
\end{tabular}

$(1,2, \ldots)$ - numbers in brackets represent the number of organizational culture features which are ascribed the particular assessment; if in case of modes the numbers do not sum to 5 multimodal distribution appeared for some features of organizational culture

Source: own study.

\section{Local Innovation and Network Commoners (SOM 3)}

The third cluster - SOM3 - includes firms called "local innovation and network commoners" as they present low internationalization, moderate innovativeness, and a moderate degree of networking. Power distance (PD) is at a moderate low level in this sample, indicated by the majority of the descriptive statistics for the cultural features within this dimension. The Individualism (IDV) might be evaluated as ranging from moderate to moderately high with the prevalence of moderate indications. The level of uncertainty avoidance (UA) is more diversified when it comes to modes and medians but, in general, it may be assessed as moderately high. The long-term orientation clearly tends towards moderately high for the majority of organizational culture features comprising the dimension (Table 6). 
Table 6. Evaluation of the organizational culture features within the Hofstede's dimensions in SOM3 $(n=39)$

\begin{tabular}{|l|l|l|l|}
\hline \multirow{2}{*}{$\begin{array}{c}\text { Organizational culture } \\
\text { dimension }\end{array}$} & \multicolumn{3}{|c|}{ Evaluation of organizational culture features } \\
\cline { 2 - 4 } power distance & by dominant value (Mo) & by central value (Me) & \multicolumn{1}{c|}{ by mean values (M) } \\
\hline individualism & $\begin{array}{l}\text { low (2) } \\
\text { moderate low (2) }\end{array}$ & $\begin{array}{l}\text { low (1) } \\
\text { moderate low (4) }\end{array}$ & $\begin{array}{l}\text { moderate low (4) } \\
\text { moderate (1) }\end{array}$ \\
\hline uncertainty avoidance & $\begin{array}{l}\text { low (1) } \\
\text { moderate low (1) } \\
\text { moderate high (3) }\end{array}$ & $\begin{array}{l}\text { moderate low (1) } \\
\text { moderate (2) } \\
\text { moderate high (2) }\end{array}$ & $\begin{array}{l}\text { moderate (4) } \\
\text { moderate high (1) }\end{array}$ \\
\hline $\begin{array}{l}\text { moderate low (1) } \\
\text { high (1) }\end{array}$ & $\begin{array}{l}\text { moderate low (1) } \\
\text { moderate (2) } \\
\text { moderate high (2) }\end{array}$ & $\begin{array}{l}\text { moderate (1) } \\
\text { moderate high (4) }\end{array}$ \\
\hline long-term orientation & $\begin{array}{l}\text { moderate (1) } \\
\text { moderate high (3) } \\
\text { high (1) }\end{array}$ & $\begin{array}{l}\text { moderate (1) } \\
\text { moderate high (4) }\end{array}$ \\
\hline
\end{tabular}

$(1,2, \ldots)$ - numbers in brackets represent the number of organizational culture features which are ascribed the particular assessment; if in case of modes the numbers do not sum to 5 multimodal distribution appeared for some features of organizational culture Source: own study.

\section{Local innovation and network laggards (SOM 4)}

The last cluster - SOM4 - embraces firms labelled "local innovation and network laggards" whose internationalization, innovativeness as well as networking are low. Firms in the cluster are characterized by moderate power distance (PD). The results for individualism (IND) offer a mixed picture ranging from moderately low to moderately high; hence, the moderate level might be a proper evaluation of the dimension. The uncertainty avoidance (UA) tends to be moderately high while the long-term orientation (LTO) that shows mixed results may be considered tending towards a moderately high level of the organizational culture features comprising the dimension (Table 7).

Table 7. Evaluation of the organizational culture features within the Hofstede's dimensions in SOM4 $(n=19)$

\begin{tabular}{|l|l|l|l|}
\hline \multirow{2}{*}{$\begin{array}{c}\text { Organizational culture } \\
\text { dimension }\end{array}$} & \multicolumn{3}{|c|}{ Evaluation of organizational culture features } \\
\cline { 2 - 4 } power distance & \multicolumn{1}{|c|}{$\begin{array}{l}\text { by dominant value (Mo) } \\
\text { low (2) } \\
\text { moderate high (1) }\end{array}$} & $\begin{array}{l}\text { moderate low (1) } \\
\text { moderate (4) }\end{array}$ & $\begin{array}{l}\text { moderate low (1) } \\
\text { moderate (4) }\end{array}$ \\
\hline individualism & $\begin{array}{l}\text { moderate low (2) } \\
\text { high (1) }\end{array}$ & $\begin{array}{l}\text { moderate low (3) } \\
\text { moderate high (2) }\end{array}$ & $\begin{array}{l}\text { moderate (4) } \\
\text { moderate high (1) }\end{array}$ \\
\hline \multirow{2}{*}{ uncertainty avoidance } & $\begin{array}{l}\text { moderate low (1) } \\
\text { moderate high (2) } \\
\text { high (1) }\end{array}$ & $\begin{array}{l}\text { moderate (1) } \\
\text { moderate high (4) }\end{array}$ & $\begin{array}{l}\text { moderate (2) } \\
\text { moderate high (3) }\end{array}$ \\
\hline long-term orientation & $\begin{array}{l}\text { moderate high (3) } \\
\text { high (2) }\end{array}$ & $\begin{array}{l}\text { moderate (1) } \\
\text { moderate high (4) }\end{array}$ & $\begin{array}{l}\text { moderate (4) } \\
\text { moderate high (1) }\end{array}$ \\
\hline
\end{tabular}

$(1,2, \ldots)$ - numbers in brackets represent the number of organizational culture features which are ascribed the particular assessment; if in case of modes the numbers do not sum to 5 multimodal distribution appeared for some features of organizational culture Source: own study. 
The analysis of results of the study for individual SOMs, i.e. clusters with different behaviours of firms in the area of internationalization, innovativeness and networking, shows few differences in the organizational culture dimensions depicted by the descriptive statistics of organizational culture features presented above. A summary of the findings is included in table 8 .

Table 8. Comparative analysis of the organizational culture features evaluations for individual SOMs

\begin{tabular}{|c|c|c|c|c|}
\hline$\stackrel{\frac{c}{0}}{\frac{0}{\mathfrak{d}}}$ & $\begin{array}{c}\text { SOM1 } \\
\text { international network } \\
\text { and innovation } \\
\text { high-fliers }\end{array}$ & $\begin{array}{c}\text { SOM2 } \\
\text { local innovation } \\
\text { and network } \\
\text { front-runners }\end{array}$ & $\begin{array}{c}\text { SOM3 } \\
\text { local innovation } \\
\text { and network commoners }\end{array}$ & $\begin{array}{c}\text { SOM4 } \\
\text { local innovation } \\
\text { and network } \\
\text { laggards }\end{array}$ \\
\hline$\frac{ \pm}{3}$ & $\begin{array}{l}\text { - moderate internation- } \\
\text { alization } \\
\text { - high innovativeness } \\
\text { - high networking } \\
\end{array}$ & $\begin{array}{l}\text { - low internationalization } \\
\text { - moderate innovative- } \\
\text { ness } \\
\text { - high networking }\end{array}$ & $\begin{array}{l}\text { - low internationalization } \\
\text { - moderate innovative- } \\
\text { ness } \\
\text { - moderate networking }\end{array}$ & $\begin{array}{l}\text { - low internationalization } \\
\text { - low innovativeness } \\
\text { - low networking }\end{array}$ \\
\hline$P D$ & moderate & moderate low & moderate & moderate \\
\hline IDV & moderate & moderate & moderate & moderate \\
\hline UA & moderate & moderate & moderate high & moderate high \\
\hline LTO & moderate high & moderate high & moderate high & moderate high \\
\hline
\end{tabular}

Source: own study.

The comparative study shows that, for SOM1 and SOM2 that differ essentially with the degree of internationalization and innovativeness, a divergence appears in the case of the power distance only, which is higher for the international network and innovation high-fliers. Higher uncertainty avoidance is a distinctive organizational culture characteristic of local innovation and network commoners (SOM3) representing a lower degree of networking than in the case of firms belonging to SOM1 and SOM2. SOM4 comprised of local innovation and network laggards in the field of internationalization, innovativeness and networking shares the same level of the four culture dimensions as SOM3. And again, a moderately high level of the long-term orientation - the same for all four SOMs - is the most surprising feature here.

The findings of the study are satisfying to a degree. They show that a higher power distance is needed for a firm to become an international network and innovation highflier. International high-fliers or local front-runners are characterized by lower uncertainty avoidance than local innovation and network commoners and laggards.

The long-term orientation as conceptualized in the study is not a dimension that differentiates the behaviour of firms in the area of internationalization, innovativeness and networking. One of the possible explanations of the fact is that it was much easier for the respondents to guess the "favoured answers" in the case of statements relating to the organization culture features constituting the long-term orientation dimension, which means that the social desirability bias might underlie the results.

\section{CONCLUSIONS}

The study as an explorative one may serve to pose two hypotheses for further research. The first one is that higher power distance may be conducive for dealing with moderate 
individualism if the ambitious aims of the firms' internationalization and innovativeness are to be achieved. The second one is a presumption that a lower uncertainty avoidance may be indicative of a higher openness for new opportunities and risk acceptance leading to a higher degree of internationalization, innovativeness and networking in firms.

The study presented here has many limitations. Firstly, the analysis is based on a nonrepresentative sample, which means that the findings only refer to the population under study. Secondly, there is the differentiation of the positions occupied in the firms by the respondents participating in the survey, which may have influenced certain answers and the achieved results. Thirdly, there is the construction of the research instrument that includes statements concerning organizational culture features giving inconsistent results within particular culture dimensions. The analysis of the three descriptive statistics shows a variety of answers appearing within individual culture dimensions representing very different or even opposite levels of the culture characteristics.

To make up for the inconsistencies, an attempt could be made in the further analysis of the organizational culture to create more consistent measures of organizational culture dimensions. Individual features of the firms' organizational culture could be considered formative variables constituting indices that can be measures of the organizational power distance, individualism, uncertainty avoidance and long-term orientation. Perhaps a change of the methodological approach would make it possible to obtain more sound results regarding the relationships between the organizational culture of firms and their behaviour as regards the internationalization, innovativeness and networking.

\section{REFERENCES}

Andersen, O. (1993). On the internationalization process of firms: a critical analysis. Journal of International Business Studies, 24(2), 209-231.

Basile, R. (2001). Export behaviour of Italian manufacturing firms over the nineties: the role of innovation. Research Policy, 30(8), 1185-1201.

Becker, S.O., \& Egger, P.H. (2013). Endogenous product versus process innovation and a firm's propensity to export. Empirical Economics, 44(1), 329-354.

Bell, J. (1995). The internationalization of small computer software firms: A further challenge to "stage" theories. European Journal of Marketing, 29(8), 60-75.

Blomstermo, A., Eriksson, K., Lindstrand, A., \& Sharma, D.D. (2004). The perceived usefulness of network experiential knowledge in the internationalizing firm. Journal of International Management, 10(3), 355-373.

Boski, P. (2009). Kulturowe ramy zachowań społecznych. Podręcznik psychologii międzykulturowej. Warszawa: Wydawnictwo Naukowe PWN.

Calantone, R.J., Cavusgil, S.T., \& Zhao, Y. (2002). Learning orientation, firm innovation capability, and firm performance. Industrial Marketing Management, 31(6), 515-524.

Coviello, N.E. (2006). The network dynamics of international new ventures. Journal of International Business Studies, 37(5), 713-731.

Coviello, N.E., \& Munro, H.J. (1995). Growing the entrepreneurial firm: networking for international market development. European Journal of Marketing, 29(7), 49-61.

Dhanaraj, C., \& Parkhe, A. (2006). Orchestrating innovation networks. Academy of Management Review, 31(3), 659-669. 
Eriksson, K., Majkgård, A., \& Sharma, D.D. (2000). Path dependence and knowledge development in the internationalization process. Management International Review, 40(4), 307-328.

Forsgren, M. (2002). The concept of learning in the Uppsala internationalization process model: A critical review. International Business Review, 11(3), 257-277.

Gupta, A.K., \& Govindarajan, V. (2000). Knowledge flows within multinational corporations. Strategic Management Journal, 21(4), 473-496.

Hayton, J.C., George, G., \& Zahra, S. (2002). National culture and entrepreneurship: A review of behavioral research. Entrepreneurship Theory \& Practice, 26(4), 33.

Hofstede, G. (1980). Culture's consequences: international differences in work related values. Beverly Hills, CA: Sage.

Hofstede, G. (1995). Multilevel Research of Human Systems: Flower, Bouquets and Gardens. Human Systems Management, 14, 207-217

Hofstede, G. (2001). Culture's Consequences: Comparing Values, Behaviors, Institutions, and Organizations across Nations. Second Edition. Thousand Oaks CA: Sage Publications.

Hofstede, G., Hostede, G., \& Minkov, M. (2011). Kultury i organizacje. Zaprogramowanie umysłu. Warszawa: Polskie Wydawnictwo Ekonomiczne.

Johanson, J., \& Mattsson, L.G. (1988). Internationalisation in Industrial Systems - a Network Approach. In N. Hood \& J.E. Vahlne (Eds.), Strategies in Global Competition (pp. 303-321). New York: Croom Helm.

Johanson, J., \& Vahlne, J.E. (2009). The Uppsala internationalization process model revisited: From liability of foreignness to liability of outsidership. Journal of International Business Studies, 40(9), 1411-1431.

Jones, G.K., \& Teegen, H.J. (2001). Global R\&D activity of US MNCs: does national culture affect investment decisions? Multinational Business Review, 9(2), 1.

Kirkman, B.L., Lowe, K.B., \& Gibson, C.B. (2006). A quarter century of culture's consequences: A review of empirical research incorporating Hofstede's cultural values framework. Journal of International Business Studies, 37(3), 285-320.

Kohonen, T. (1990). The Self-Organizing Map. Proceedings of the IEEE, 78, 1464-1480.

Kosała, M. (2015). Innovation Processes as Stimulant of Internationalisation Process of Firms. Entrepreneurial Business and Economics Review, 3(2), 65-84.

Lewandowska, M., Szymura-Tyc, M., \& Gołębiowski, T. (2016), Innovation complementarity, cooperation partner, and new product export: Evidence from Poland. Journal of Business Research, 69(9), 3673-3681.

Majkgård, A., \& Sharma, D.D. (1998). Client-following and market-seeking strategies in the internationalization of service firms. Journal of Business-to-Business Marketing, 4(3), 1-41.

Manev, I.M., \& Stevenson, W.B. (2001). Nationality, cultural distance, and expatriate status: Effects on the managerial network in a multinational enterprise. Journal of International Business Studies, 32(2), 285-303.

McSweeney, B. (2002). Hofstede's model of national cultural differences and their consequences: A triumph of faith-a failure of analysis. Human relations, 55(1), 89-118.

Morris, M.H., Davis, D.L., \& Allen, J.W. (1994). Fostering corporate entrepreneurship: Cross-cultural comparisons of the importance of individualism versus collectivism. Journal of International Business Studies, 26(1) 65-89.

Osgood, C.E., Suci, G.J., \& Tannenbaum, P.H. (1957). The Measurement of Meaning. Urbana, IL: University of Illinois Press. 
Powell, W.W., Koput, K.W., \& Smith-Doerr, L. (1996). Interorganizational collaboration and the locus of innovation: Networks of learning in biotechnology. Administrative Science Quarterly, 41(1), 116-145.

Roper, S., \& Love, J.H. (2002). Innovation and export performance: Evidence from the UK and German manufacturing plants. Research Policy, 31(7), 1087-1102.

Rothwell, R. (1992). Successful industrial innovation: critical factors for the 1990s. R\&D Management, 22(3), 221-240.

Salomon, R. M., \& Shaver, J. M. (2005). Learning by exporting: new insights from examining firm innovation. Journal of Economics \& Management Strategy, 14(2), 431-460.

Salomon, R.M., \& Jin, B. (2008). Does knowledge spill to leaders or laggards? Exploring industry heterogeneity in learning by exporting. Journal of International Business Studies, 39(1), 132-150.

Shane, S. (1995). Uncertainty avoidance and the preference for innovation championing roles. Journal of International Business Studies, 26 (1), 47-68.

Shane, S., Venkataraman, S., \& MacMillan, I. (1995). Cultural differences in innovation championing strategies. Journal of Management, 21(5), 931-952.

Sharma, D.D., \& Blomstermo, A. (2003). The internationalization process of born globals: a network view. International Business Review, 12(6), 739-753.

Smith, P.B. (2002). Culture's consequences: Something old and something new. Human Relations, 55(1), 119-135.

Sułkowski, Ł. (2012). Kulturowe procesy zarzqdzania. Warszawa: Difin.

Szymura-Tyc, M., \& Łapczyński, M. (2012). Internationalisation and Innovation in Networks. In R. Springer \& P. Chadraba (Eds.), Proceedings of the $20^{\text {th }}$ Annual Conference on Marketing and Business Strategies for Central \& Eastern Europe (pp. 287-301). Vienna: Vienna University of Economics and Business.

Szymura-Tyc, M. (2015a). Innovativeness and Internationalisation of the Polish Economy - the Transition Process Perspective. Journal of Economics and Management, 21(3), 5-20.

Szymura-Tyc, M. (2015b). Internacjonalizacja, innowacyjność i usieciowienie przedsiębiorstw. Podejście holistyczne. Warszawa: Difin.

Thomas, A.S., \& Mueller, S.L. (2000). A case for comparative entrepreneurship: Assessing the relevance of culture. Journal of International Business Studies, 31(2), 287-301.

Trompenaars, F. (1993). Riding the Waves of Culture: Understanding Diversity in Global Business. Chicago IL: Irwin.

Zaheer, S., \& Zaheer, A. (1997). Country effects on information seeking in global electronic networks. Journal of International Business Studies, 28(1), 77-100.

Zahra, S.A., Ireland, R.D., \& Hitt, M.A. (2000). International expansion by new venture firms: International diversity, mode of market entry, technological learning, and performance. Academy of Management Journal, 43(5), 925-950. 


\section{Appendix 1: Descriptive statistics for organizational culture features within Hofstede's dimensions in the entire sample}

\begin{tabular}{|c|c|c|c|c|c|}
\hline \multicolumn{2}{|c|}{ Entire sample } & \multirow{2}{*}{$\begin{array}{l}\text { Mo } \\
2\end{array}$} & \multirow{2}{*}{ Me } & \multirow{2}{*}{ M } & \multirow[b]{2}{*}{ Subordinates are dependent on superiors } \\
\hline \multirow{5}{*}{ 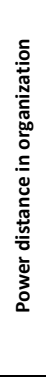 } & Subordinates and superiors are co-dependent & & & & \\
\hline & $\begin{array}{l}\text { Superiors consult their decisions with } \\
\text { subordinates using their own experience and the } \\
\text { experience of subordinates }\end{array}$ & 3 & 3.5 & 4.08 & $\begin{array}{l}\text { Superiors make decisions without consultations } \\
\text { with subordinates on the basis of the superiors' } \\
\text { experience and formal regulations }\end{array}$ \\
\hline & $\begin{array}{l}\text { Occupying top positions does not entail } \\
\text { substantially higher salaries and special privileges }\end{array}$ & 2 & 3 & 3.52 & $\begin{array}{l}\text { Occupying top positions entails substantially higher } \\
\text { salaries and special privileges }\end{array}$ \\
\hline & $\begin{array}{l}\text { Employees occupying lower positions perform } \\
\text { different roles in the enterprise than employees } \\
\text { on higher levels }\end{array}$ & 5 & 4 & 3.95 & $\begin{array}{l}\text { Employees occupying lower positions have lesser } \\
\text { abilities and skills than employees on higher levels }\end{array}$ \\
\hline & $\begin{array}{l}\text { Important decisions are made on different levels } \\
\text { and do not require strict control in the course of } \\
\text { their execution }\end{array}$ & 2 & 3 & 3.69 & $\begin{array}{l}\text { Important decisions are made on top levels and } \\
\text { require strict control in the course of their } \\
\text { execution }\end{array}$ \\
\hline \multirow{5}{*}{ 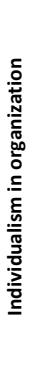 } & $\begin{array}{l}\text { Employees strive to act in the interest of the } \\
\text { group they are part of }\end{array}$ & 5 & 4 & 3.77 & Employees strive to act in their own interest \\
\hline & $\begin{array}{l}\text { Decisions concerning employees' salary and } \\
\text { promotion depend on their membership in a } \\
\text { group and achievements of the group }\end{array}$ & 3 & 4 & 4.24 & $\begin{array}{l}\text { Decisions concerning employees' salary and } \\
\text { promotion depend on the regulations in force and } \\
\text { their individual achievements }\end{array}$ \\
\hline & $\begin{array}{l}\text { Even if someone has a different opinion, she/he } \\
\text { should adapt to the opinion of the collective }\end{array}$ & 5 & 4. 5 & 4.16 & $\begin{array}{l}\text { Everyone can have a different opinion and is } \\
\text { expected to express it }\end{array}$ \\
\hline & $\begin{array}{l}\text { Interpersonal relations are more important than } \\
\text { the execution of tasks }\end{array}$ & 5 & 4 & 4.16 & $\begin{array}{l}\text { The execution of tasks is more important than } \\
\text { interpersonal relations }\end{array}$ \\
\hline & $\begin{array}{l}\text { Relations between the employer and the } \\
\text { employee resemble family ties }\end{array}$ & 5 & 4 & 4.04 & $\begin{array}{l}\text { Relations between the employer and the employee } \\
\text { are reduced to the employment contract }\end{array}$ \\
\hline \multirow{5}{*}{ 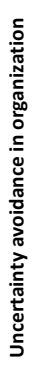 } & $\begin{array}{l}\text { Change is more desirable than preservation of the } \\
\text { current situation }\end{array}$ & 3 & 4 & 3.67 & $\begin{array}{l}\text { Preservation of the current situation is more } \\
\text { desirable than a change }\end{array}$ \\
\hline & $\begin{array}{l}\text { Innovative and creative employees have more } \\
\text { freedom }\end{array}$ & 5 & 5 & 4.42 & $\begin{array}{l}\text { Innovative and creative employees are limited by } \\
\text { regulations }\end{array}$ \\
\hline & $\begin{array}{l}\text { Managers mainly focus on strategic issues and, to } \\
\text { a lesser degree, on operational activities }\end{array}$ & 6 & 5 & 4.53 & $\begin{array}{l}\text { Managers mainly focus on operational activities } \\
\text { and, to a lesser degree, on strategic issues }\end{array}$ \\
\hline & $\begin{array}{l}\text { Few matters are regulated in detailed regulations } \\
\text { and they are usually complied with }\end{array}$ & 5 & 4 & 3.88 & $\begin{array}{l}\text { Many matters are regulated in detailed regulations } \\
\text { but they are not always complied with }\end{array}$ \\
\hline & $\begin{array}{l}\text { Many ideas/inventions are generated but not all } \\
\text { are implemented }\end{array}$ & 5 & 5 & 4.36 & $\begin{array}{l}\text { Few ideas/inventions are generated but most of } \\
\text { them are implemented }\end{array}$ \\
\hline \multirow{5}{*}{ 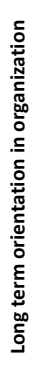 } & $\begin{array}{l}\text { Actions taken are evaluated from the perspective } \\
\text { of their effects in annual periods }\end{array}$ & 6 & 5 & 4.68 & $\begin{array}{l}\text { Actions taken are evaluated from the perspective of } \\
\text { their effects in many years' periods }\end{array}$ \\
\hline & $\begin{array}{l}\text { Relations with business partners are evaluated } \\
\text { from the perspective of short-term profits }\end{array}$ & 6 & 5 & 4.17 & $\begin{array}{l}\text { Relations with business partners are evaluated from } \\
\text { the perspective of long-term profits }\end{array}$ \\
\hline & $\begin{array}{l}\text { Meeting the deadline for a task completion is } \\
\text { more important than attaining an expected result }\end{array}$ & 6 & 4 & 4.27 & $\begin{array}{l}\text { Attaining an expected result is more important than } \\
\text { meeting the deadline for a task completion }\end{array}$ \\
\hline & $\begin{array}{l}\text { A fast, spectacular market or financial success is } \\
\text { more important than the gradual building of a } \\
\text { strong market position }\end{array}$ & 5 & 5 & 4.47 & $\begin{array}{l}\text { Building of a strong market position gradually is } \\
\text { more important than a fast, spectacular market or } \\
\text { financial success }\end{array}$ \\
\hline & $\begin{array}{l}\text { Objectives of the managerial staff and employees } \\
\text { diverge }\end{array}$ & 6 & 5 & 4.45 & $\begin{array}{l}\text { Objectives of the managerial staff and employees } \\
\text { converge }\end{array}$ \\
\hline
\end{tabular}

Source: own study. 


\section{Appendix 2: Descriptive statistics for organizational culture features within Hofstede's dimensions in SOMs}

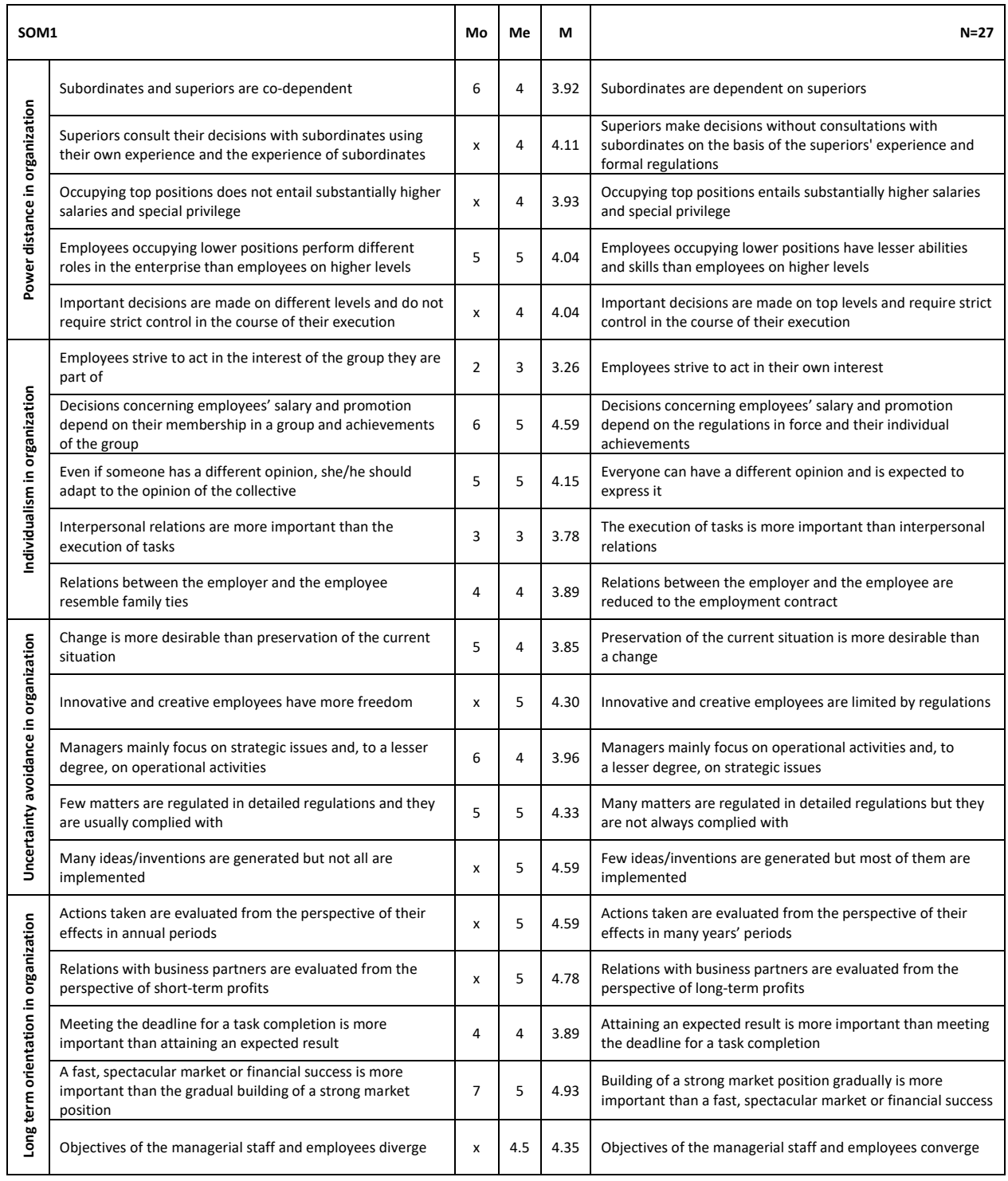

$(x)$ - multimodal distribution 


\begin{tabular}{|c|c|c|c|c|c|}
\hline \multicolumn{2}{|c|}{ SOM2 } & \multirow{2}{*}{$\begin{array}{l}\text { Mo } \\
2\end{array}$} & \multirow{2}{*}{ Me } & \multirow{2}{*}{ M } & $\mathrm{N}=48$ \\
\hline \multirow{5}{*}{ 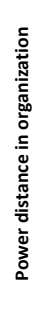 } & Subordinates and superiors are co-dependent & & & & Subordinates are dependent on superiors \\
\hline & $\begin{array}{l}\text { Superiors consult their decisions with subordinates using } \\
\text { their own experience and the experience of subordinates }\end{array}$ & 2 & 3 & 4.00 & $\begin{array}{l}\text { Superiors make decisions without consultations with } \\
\text { subordinates on the basis of the superiors' experience and } \\
\text { formal regulations }\end{array}$ \\
\hline & $\begin{array}{l}\text { Occupying top positions does not entail substantially higher } \\
\text { salaries and special privilege }\end{array}$ & 2 & 3 & 3.54 & $\begin{array}{l}\text { Occupying top positions entails substantially higher salaries } \\
\text { and special privilege }\end{array}$ \\
\hline & $\begin{array}{l}\text { Employees occupying lower positions perform different } \\
\text { roles in the enterprise than employees on higher levels }\end{array}$ & 5 & 4.5 & 4.08 & $\begin{array}{l}\text { Employees occupying lower positions have lesser abilities } \\
\text { and skills than employees on higher levels }\end{array}$ \\
\hline & $\begin{array}{l}\text { Important decisions are made on different levels and do not } \\
\text { require strict control in the course of their execution }\end{array}$ & 2 & 3 & 3.56 & $\begin{array}{l}\text { Important decisions are made on top levels and require strict } \\
\text { control in the course of their execution }\end{array}$ \\
\hline \multirow{5}{*}{ 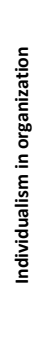 } & $\begin{array}{l}\text { Employees strive to act in the interest of the group they are } \\
\text { part of }\end{array}$ & 5 & 4 & 3.77 & Employees strive to act in their own interest \\
\hline & $\begin{array}{l}\text { Decisions concerning employees' salary and promotion } \\
\text { depend on their membership in a group and achievements } \\
\text { of the group }\end{array}$ & 3 & 4 & 4.23 & $\begin{array}{l}\text { Decisions concerning employees' salary and promotion } \\
\text { depend on the regulations in force and their individual } \\
\text { achievements }\end{array}$ \\
\hline & $\begin{array}{l}\text { Even if someone has a different opinion, she/he should } \\
\text { adapt to the opinion of the collective }\end{array}$ & 6 & 4.5 & 4.27 & $\begin{array}{l}\text { Everyone can have a different opinion and is expected to } \\
\text { express it }\end{array}$ \\
\hline & $\begin{array}{l}\text { Interpersonal relations are more important than the } \\
\text { execution of tasks }\end{array}$ & 5 & 4 & 4.15 & $\begin{array}{l}\text { The execution of tasks is more important than interpersonal } \\
\text { relations }\end{array}$ \\
\hline & $\begin{array}{l}\text { Relations between the employer and the employee } \\
\text { resemble family ties }\end{array}$ & 4 & 4 & 4.17 & $\begin{array}{l}\text { Relations between the employer and the employee are } \\
\text { reduced to the employment contract }\end{array}$ \\
\hline \multirow{5}{*}{ 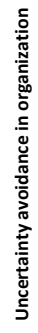 } & $\begin{array}{l}\text { Change is more desirable than preservation of the current } \\
\text { situation }\end{array}$ & 2 & 3.5 & 3.65 & $\begin{array}{l}\text { Preservation of the current situation is more desirable than } \\
\text { a change }\end{array}$ \\
\hline & Innovative and creative employees have more freedom & 6 & 5 & 4.40 & Innovative and creative employees are limited by regulations \\
\hline & $\begin{array}{l}\text { Managers mainly focus on strategic issues and, to a lesser } \\
\text { degree, on operational activities }\end{array}$ & 5 & 5 & 4.81 & $\begin{array}{l}\text { Managers mainly focus on operational activities and, to } \\
\text { a lesser degree, on strategic issues }\end{array}$ \\
\hline & $\begin{array}{l}\text { Few matters are regulated in detailed regulations and they } \\
\text { are usually complied with }\end{array}$ & 5 & 3 & 3.60 & $\begin{array}{l}\text { Many matters are regulated in detailed regulations but they } \\
\text { are not always complied with }\end{array}$ \\
\hline & $\begin{array}{l}\text { Many ideas/inventions are generated but not all are } \\
\text { implemented }\end{array}$ & 5 & 4 & 4.17 & $\begin{array}{l}\text { Few ideas/inventions are generated but most of them are } \\
\text { implemented }\end{array}$ \\
\hline \multirow{5}{*}{ 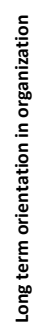 } & $\begin{array}{l}\text { Actions taken are evaluated from the perspective of their } \\
\text { effects in annual periods }\end{array}$ & 3 & 4.5 & 4.40 & $\begin{array}{l}\text { Actions taken are evaluated from the perspective of their } \\
\text { effects in many years' periods }\end{array}$ \\
\hline & $\begin{array}{l}\text { Relations with business partners are evaluated from the } \\
\text { perspective of short-term profits }\end{array}$ & 5 & 5 & 4.23 & $\begin{array}{l}\text { Relations with business partners are evaluated from the } \\
\text { perspective of long-term profits }\end{array}$ \\
\hline & $\begin{array}{l}\text { Meeting the deadline for a task completion is more } \\
\text { important than attaining an expected result }\end{array}$ & 6 & 4 & 4.13 & $\begin{array}{l}\text { Attaining an expected result is more important than meeting } \\
\text { the deadline for a task completion }\end{array}$ \\
\hline & $\begin{array}{l}\text { A fast, spectacular market or financial success is more } \\
\text { important than the gradual building of a strong market } \\
\text { position }\end{array}$ & $\mathrm{x}$ & 5 & 4.33 & $\begin{array}{l}\text { Building of a strong market position gradually is more } \\
\text { important than a fast, spectacular market or financial success }\end{array}$ \\
\hline & Objectives of the managerial staff and employees diverge & 6 & 5 & 4.45 & Objectives of the managerial staff and employees converge \\
\hline
\end{tabular}

$(x)$ - multimodal distribution 


\begin{tabular}{|c|c|c|c|c|c|}
\hline \multicolumn{2}{|c|}{ SOM3 } & \multirow{2}{*}{$\begin{array}{c}\text { Mo } \\
x\end{array}$} & \multirow{2}{*}{$\begin{array}{c}\text { Me } \\
3\end{array}$} & \multirow{2}{*}{$\begin{array}{c}\mathbf{M} \\
3.28\end{array}$} & \multirow[b]{2}{*}{ Subordinates are dependent on superiors } \\
\hline \multirow{5}{*}{ 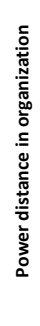 } & Subordinates and superiors are co-dependent & & & & \\
\hline & $\begin{array}{l}\text { Superiors consult their decisions with subordinates using } \\
\text { their own experience and the experience of subordinates }\end{array}$ & 3 & 3 & 3.19 & $\begin{array}{l}\text { Superiors make decisions without consultations with } \\
\text { subordinates on the basis of the superiors' experience and } \\
\text { formal regulations }\end{array}$ \\
\hline & $\begin{array}{l}\text { Occupying top positions does not entail substantially higher } \\
\text { salaries and special privilege }\end{array}$ & 2 & 2 & 3.22 & $\begin{array}{l}\text { Occupying top positions entails substantially higher salaries } \\
\text { and special privilege }\end{array}$ \\
\hline & $\begin{array}{l}\text { Employees occupying lower positions perform different } \\
\text { roles in the enterprise than employees on higher levels }\end{array}$ & 3 & 3 & 3.86 & $\begin{array}{l}\text { Employees occupying lower positions have lesser abilities } \\
\text { and skills than employees on higher levels }\end{array}$ \\
\hline & $\begin{array}{l}\text { Important decisions are made on different levels and do not } \\
\text { require strict control in the course of their execution }\end{array}$ & 2 & 3 & 3.36 & $\begin{array}{l}\text { Important decisions are made on top levels and require strict } \\
\text { control in the course of their execution }\end{array}$ \\
\hline \multirow{5}{*}{ 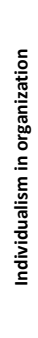 } & $\begin{array}{l}\text { Employees strive to act in the interest of the group they are } \\
\text { part of }\end{array}$ & 5 & 5 & 4.22 & Employees strive to act in their own interest \\
\hline & $\begin{array}{l}\text { Decisions concerning employees' salary and promotion } \\
\text { depend on their membership in a group and achievements } \\
\text { of the group }\end{array}$ & 3 & 3 & 3.92 & $\begin{array}{l}\text { Decisions concerning employees' salary and promotion } \\
\text { depend on the regulations in force and their individual } \\
\text { achievements }\end{array}$ \\
\hline & $\begin{array}{l}\text { Even if someone has a different opinion, she/he should } \\
\text { adapt to the opinion of the collective }\end{array}$ & 2 & 3.5 & 3.81 & $\begin{array}{l}\text { Everyone can have a different opinion and is expected to } \\
\text { express it }\end{array}$ \\
\hline & $\begin{array}{l}\text { Interpersonal relations are more important than the } \\
\text { execution of tasks }\end{array}$ & 5 & 5 & 4.72 & $\begin{array}{l}\text { The execution of tasks is more important than interpersonal } \\
\text { relations }\end{array}$ \\
\hline & $\begin{array}{l}\text { Relations between the employer and the employee } \\
\text { resemble family ties }\end{array}$ & 5 & 4 & 4.17 & $\begin{array}{l}\text { Relations between the employer and the employee are } \\
\text { reduced to the employment contract }\end{array}$ \\
\hline \multirow{5}{*}{ 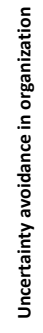 } & $\begin{array}{l}\text { Change is more desirable than preservation of the current } \\
\text { situation }\end{array}$ & 3 & 3 & 3.56 & $\begin{array}{l}\text { Preservation of the current situation is more desirable than } \\
\text { a change }\end{array}$ \\
\hline & Innovative and creative employees have more freedom & 5 & 5 & 4.44 & Innovative and creative employees are limited by regulations \\
\hline & $\begin{array}{l}\text { Managers mainly focus on strategic issues and, to a lesser } \\
\text { degree, on operational activities }\end{array}$ & 6 & 5 & 4.50 & $\begin{array}{l}\text { Managers mainly focus on operational activities and, to } \\
\text { a lesser degree, on strategic issues }\end{array}$ \\
\hline & $\begin{array}{l}\text { Few matters are regulated in detailed regulations and they } \\
\text { are usually complied with }\end{array}$ & $\mathrm{x}$ & 3.5 & 3.78 & $\begin{array}{l}\text { Many matters are regulated in detailed regulations but they } \\
\text { are not always complied with }\end{array}$ \\
\hline & $\begin{array}{l}\text { Many ideas/inventions are generated but not all are } \\
\text { implemented }\end{array}$ & $\mathrm{x}$ & 4 & 4.36 & $\begin{array}{l}\text { Few ideas/inventions are generated but most of them are } \\
\text { implemented }\end{array}$ \\
\hline \multirow{5}{*}{ 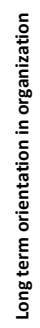 } & $\begin{array}{l}\text { Actions taken are evaluated from the perspective of their } \\
\text { effects in annual periods }\end{array}$ & 6 & 6 & 5.11 & $\begin{array}{l}\text { Actions taken are evaluated from the perspective of their } \\
\text { effects in many years' periods }\end{array}$ \\
\hline & $\begin{array}{l}\text { Relations with business partners are evaluated from the } \\
\text { perspective of short-term profits }\end{array}$ & 6 & 3.5 & 3.89 & $\begin{array}{l}\text { Relations with business partners are evaluated from the } \\
\text { perspective of long-term profits }\end{array}$ \\
\hline & $\begin{array}{l}\text { Meeting the deadline for a task completion is more } \\
\text { important than attaining an expected result }\end{array}$ & 6 & 5 & 4.66 & $\begin{array}{l}\text { Attaining an expected result is more important than meeting } \\
\text { the deadline for a task completion }\end{array}$ \\
\hline & $\begin{array}{l}\text { A fast, spectacular market or financial success is more } \\
\text { important than the gradual building of a strong market } \\
\text { position }\end{array}$ & 5 & 5 & 4.67 & $\begin{array}{l}\text { Building of a strong market position gradually is more } \\
\text { important than a fast, spectacular market or financial success }\end{array}$ \\
\hline & Objectives of the managerial staff and employees diverge & 5 & 5 & 4.76 & Objectives of the managerial staff and employees converge \\
\hline
\end{tabular}

(x) - multimodal distribution 


\begin{tabular}{|c|c|c|c|c|c|}
\hline \multicolumn{2}{|c|}{ SOM4 } & \multirow{2}{*}{ Mo } & \multirow{2}{*}{$\begin{array}{l}\text { Me } \\
3.5\end{array}$} & \multirow{2}{*}{ M } & \multirow[b]{2}{*}{ Subordinates are dependent on superiors } \\
\hline \multirow{5}{*}{ 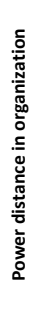 } & Subordinates and superiors are co-dependent & & & & \\
\hline & $\begin{array}{l}\text { Superiors consult their decisions with subordinates using } \\
\text { their own experience and the experience of subordinates }\end{array}$ & 2 & 4 & 4.00 & $\begin{array}{l}\text { Superiors make decisions without consultations with } \\
\text { subordinates on the basis of the superiors' experience and } \\
\text { formal regulations }\end{array}$ \\
\hline & $\begin{array}{l}\text { Occupying top positions does not entail substantially higher } \\
\text { salaries and special privilege }\end{array}$ & $\mathrm{x}$ & 3 & 3.47 & $\begin{array}{l}\text { Occupying top positions entails substantially higher salaries } \\
\text { and special privilege }\end{array}$ \\
\hline & $\begin{array}{l}\text { Employees occupying lower positions perform different } \\
\text { roles in the enterprise than employees on higher levels }\end{array}$ & 5 & 4 & 3.68 & $\begin{array}{l}\text { Employees occupying lower positions have lesser abilities } \\
\text { and skills than employees on higher levels }\end{array}$ \\
\hline & $\begin{array}{l}\text { Important decisions are made on different levels and do not } \\
\text { require strict control in the course of their execution }\end{array}$ & 2 & 4 & 4.16 & $\begin{array}{l}\text { Important decisions are made on top levels and require strict } \\
\text { control in the course of their execution }\end{array}$ \\
\hline \multirow{5}{*}{ 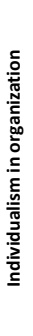 } & $\begin{array}{l}\text { Employees strive to act in the interest of the group they are } \\
\text { part of }\end{array}$ & $\mathrm{x}$ & 3 & 3.63 & Employees strive to act in their own interest \\
\hline & $\begin{array}{l}\text { Decisions concerning employees' salary and promotion } \\
\text { depend on their membership in a group and achievements } \\
\text { of the group }\end{array}$ & 6 & 5 & 4.37 & $\begin{array}{l}\text { Decisions concerning employees' salary and promotion } \\
\text { depend on the regulations in force and their individual } \\
\text { achievements }\end{array}$ \\
\hline & $\begin{array}{l}\text { Even if someone has a different opinion, she/he should } \\
\text { adapt to the opinion of the collective }\end{array}$ & $\mathrm{x}$ & 5 & 4.58 & $\begin{array}{l}\text { Everyone can have a different opinion and is expected to } \\
\text { express it }\end{array}$ \\
\hline & $\begin{array}{l}\text { Interpersonal relations are more important than the } \\
\text { execution of tasks }\end{array}$ & 3 & 3 & 3.61 & $\begin{array}{l}\text { The execution of tasks is more important than interpersonal } \\
\text { relations }\end{array}$ \\
\hline & $\begin{array}{l}\text { Relations between the employer and the employee } \\
\text { resemble family ties }\end{array}$ & 3 & 3 & 3.68 & $\begin{array}{l}\text { Relations between the employer and the employee are } \\
\text { reduced to the employment contract }\end{array}$ \\
\hline \multirow{5}{*}{ 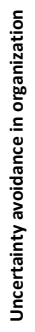 } & $\begin{array}{l}\text { Change is more desirable than preservation of the current } \\
\text { situation }\end{array}$ & 3 & 4 & 3.68 & $\begin{array}{l}\text { Preservation of the current situation is more desirable than } \\
\text { a change }\end{array}$ \\
\hline & Innovative and creative employees have more freedom & 6 & 5 & 4.58 & Innovative and creative employees are limited by regulations \\
\hline & $\begin{array}{l}\text { Managers mainly focus on strategic issues and, to a lesser } \\
\text { degree, on operational activities }\end{array}$ & 5 & 5 & 4.68 & $\begin{array}{l}\text { Managers mainly focus on operational activities and, to } \\
\text { a lesser degree, on strategic issues }\end{array}$ \\
\hline & $\begin{array}{l}\text { Few matters are regulated in detailed regulations and they } \\
\text { are usually complied with }\end{array}$ & 5 & 5 & 4.16 & $\begin{array}{l}\text { Many matters are regulated in detailed regulations but they } \\
\text { are not always complied with }\end{array}$ \\
\hline & $\begin{array}{l}\text { Many ideas/inventions are generated but not all are } \\
\text { implemented }\end{array}$ & $\mathrm{x}$ & 5 & 4.53 & $\begin{array}{l}\text { Few ideas/inventions are generated but most of them are } \\
\text { implemented }\end{array}$ \\
\hline \multirow{5}{*}{ 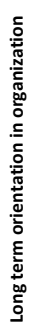 } & $\begin{array}{l}\text { Actions taken are evaluated from the perspective of their } \\
\text { effects in annual periods }\end{array}$ & 6 & 5 & 4.68 & $\begin{array}{l}\text { Actions taken are evaluated from the perspective of their } \\
\text { effects in many years' periods }\end{array}$ \\
\hline & $\begin{array}{l}\text { Relations with business partners are evaluated from the } \\
\text { perspective of short-term profits }\end{array}$ & 6 & 4 & 3.68 & $\begin{array}{l}\text { Relations with business partners are evaluated from the } \\
\text { perspective of long-term profits }\end{array}$ \\
\hline & $\begin{array}{l}\text { Meeting the deadline for a task completion is more } \\
\text { important than attaining an expected result }\end{array}$ & 5 & 5 & 4,42 & $\begin{array}{l}\text { Attaining an expected result is more important than meeting } \\
\text { the deadline for a task completion }\end{array}$ \\
\hline & $\begin{array}{l}\text { A fast, spectacular market or financial success is more } \\
\text { important than the gradual building of a strong market } \\
\text { position }\end{array}$ & 5 & 5 & 3.79 & $\begin{array}{l}\text { Building of a strong market position gradually is more } \\
\text { important than a fast, spectacular market or financial success }\end{array}$ \\
\hline & Objectives of the managerial staff and employees diverge & 5 & 5 & 4.05 & Objectives of the managerial staff and employees converge \\
\hline
\end{tabular}

(x) - multimodal distribution

Source: own study. 


\section{Authors}

The contribution of co-authors is $60 \%$ to $40 \%$. M. Szymura-Tyc prepared the conceptual part of the paper together with literature review and conducted the preceding study referred in the study, while M. Kucia conducted the survey and prepared the statistical calculations.

\section{Maja Szymura-Tyc}

Associate Professor of Management in the Department of International Management at the Faculty of Management of the University of Economics in Katowice (Poland). PhD in economics, Habilitation in management. Her research interests include management, marketing and international business, lately - internationalization, innovativeness of firms, and network approach in management sciences.

Correspondence to: Prof. Maja Szymura-Tyc, PhD; University of Economics in Katowice; Faculty of Management; ul. 1 Maja 50, 40-287 Katowice, Poland; email: maja.tyc@ue.katowice.pl

\section{Michał Kucia}

Assistant Professor in the Department of Markets and Consumption at the Faculty of Economics of the University of Economics in Katowice (Poland). PhD in economics (market research, e-commerce). His research interests include social media and e-commerce.

Correspondence to: Michał Kucia, PhD; University of Economics in Katowice; Faculty of Economics; ul. 1 Maja 50, 40-287 Katowice, Poland; email: michal.kucia@ue.katowice.pl

\section{Acknowledgements and Financial Disclosure}

The empirical research has been conducted within the project no. Nr N N112 303438 entitled 'Internationalization, networking and innovativeness of firms - cultural determinants', financed by the National Centre of Science (NCN, Poland) coordinated by Maja Szymura-Tyc in the years 2011- 2015. The current financial support for the study comes from the Faculty of Management of the University of Economics in Katowice.

The authors would like to thank the anonymous referees for their useful comments, which allowed enhancing the value of this article.

\section{Copyright and License}

This article is published under the terms of the Creative Commons Attribution - NonCommercial - NoDerivs (CC BY-NC-ND 3.0) License http://creativecommons.org/licenses/by-nc-nd/3.0/ 